Original Research Paper

\title{
Pertumbuhan Rumput Laut Kappaphycus alvarezii Hasil Kultur Jaringan
}

\author{
Andy Arjuni ${ }^{1}$, Nunik Cokrowati ${ }^{1 *}$, Rusman $^{2}$ \\ ${ }^{1}$ Program Studi Budidaya Perairan, Universitas Mataram, Mataram, Indnesia \\ ${ }^{2}$ Balai Budidaya Laut Lombok-Sekotong Nusa Tenggara Barat, Indonesia
}

\author{
Article history \\ Received: 20 Juli 2018 \\ Revised: 1 November 2018 \\ Accepted: 24 November 2018 \\ Published: 2 Desember 018 \\ *Corresponding Author: \\ Nunik Cokrowati, \\ Program Studi Budidaya \\ Perairan Universitas Mataram, \\ Indonesia \\ Email: \\ nunikcokrowati@unram.ac.id
}

\begin{abstract}
The purpose of this study is to determine the right planting point and seed weight to produce optimal growth Kappaphycus alvarezii. Seaweed cultivation method used is bottom off method and seed used is tissue culture seaweed. This research was conducted from February to April 2016 at Nambung beach, Sekotong Subdistrict, West Lombok regency, West Nusa Tenggara Province. This research used experimental method in field with experimental design that used is Factorial Random Design (Factorial RAL). Treatment consists of 2 factors, where the first factor is 3 different planting point (10 meters from coastline, 20 meter from coastline and 30 meters from the coastline) and the second factor is the weight of different seeds (1.5 gram and 50 gram seed weight). The results showed that the planting position of seaweed and the weight of the seeds used gave effect to absolute growth. The interaction between planting position and seed weight also gives Kappaphycus alvarezii a significantly different growth. The conclusion of this research is the use of planting point and seed weight give interaction to each other
\end{abstract}

Keywords:growth, tissue culture, bottom off method, weight, cultivated

Abstrak: Penelitian ini bertujuan untuk mengetahui titik tanam dan berat bibit yang tepat sehingga mampu menghasilkan pertumbuhan rumput laut Kappaphycus alvarezii hasil kultur jaringan yang optimal.Metode budidaya rumput laut yang digunakan adalah metode patok dasar dengan bibit rumput laut hasil kultur jaringan.Penelitian ini dilaksanakan pada bulan Februari sampai April 2016 di pantai Nambung Kecamatan Sekotong Kabupaten Lombok Barat Provinsi Nusa Tenggara Barat. Penelitian ini menggunakan metode eksperimental di lapangan dengan rancangan percobaan yang digunakan adalah Rancangan Acak Lengkap Faktorial (RAL Faktorial).Perlakuan terdiri atas 2 faktor, dimana faktor pertama merupakan 3 titik tanam yang berbeda (10 meter dari garis pantai, 20 meter dari garis pantai dan 30 meter dari garis pantai) dan faktor yang ke dua adalah berat bibit yang berbeda (Berat bibit 1,5 gram dan 50 gram). Hasil penelitian menunjukkan bahwa posisi tanam rumput laut dan berat bibit yang digunakan memberikan pengaruh terhadap pertumbuhan mutlak.Interaksi antara posisi tanam dan berat bibit juga memberikan pertumbuhan Kappaphycus alvarezii yang berbeda nyata. Kesimpulan penelitian ini adalah penggunaan titik tanam dan berat bibit memberikan interaksi satu sama lain.

Kata kunci: pertumbuhan, kultur jaringan, metode patok dasar, berat, budidaya

\section{Pendahuluan}

Jenis rumput laut unggulan Provinsi Nusa Tenggara Barat (NTB) adalah Kappaphycus alvarezii. Jenis ini mempunyai nilai ekonomis penting karena sebagai penghasil karaginan. Pada industri dan perdagangan, karaginan dapat digunakan sebagai bahan baku untuk industri farmasi, kosmetik, makanan dan lain-lain (DKP,
2014). Produksi rumput laut pada tahun 2013 tercatat hingga mencapai 756.355 ton, namun produksi ini masih bisa ditingkatkan hingga mencapai 2 kali lipat dari hasil tahun 2013 mengingat potensi laut yang dimanfaatkan sebagai lahan budidaya di NTB baru mencapai $40 \%$ dari lahan yang tersedia (KKP, 2014). Tingginya produksi rumput laut NTB mampu meningkatkan Indonesia sebagai eksportir rumput laut dunia yaitu 
sebesar 63,37\% dan mengalahkan Chile yang sebelumnya terus menjadi negara Eksportir rumput laut terbesar (KKP, 2015).

Tingginya permintaan akan Kappaphycus alvarezii sehingga menuntut para pembudidaya untuk menghasilkan rumput laut Kappaphycus alvarezii dengan cepat, banyak dan berkualitas, sedangkan keberadaan bibit unggul sering bermasalah serta langkanya bibit unggul pada musim-musim tertentu. Hal ini dikarenakan oleh bibit yang terus menerus digunakan akan mengalamai penurunan kualitas dan lambatnya pertumbuhan rumput laut itu sendiri serta rentannya bibit Kappaphycus alvarezii terserang penyakit (Anggadiredja et al., 2008). Oleh karena itu KKP bekerja sama dengan SEAMEO Biotrop berupaya untuk terus mengembangakan ketersediaan bibit unggul melalui pengembangan bibit kultur jaringan (KULJAR). Dimana bibit tersebut memiliki keunggulan baik dari segi kandungan karaginan maupun pertumbuhan yang lebih cepat dan tingkat ketahanan terhadap penyakit yang lebih tinggi (KKP, 2015).

Dalam kegiatan budidaya rumput laut pada umumnya dikenal beberapa metode pemeliharaan yang sering diterapkan oleh pembudidaya, diantaranya penggunaan metode patok dasar. Metode patok dasar adalah metode yang dilakukan pada dasar perairan yang terdiri dari pasir, sehingga mudah untuk menancapkan patok. Penanaman dengan metode ini dilakukan dengan mengikat bibit tanaman yang telah dipotong pada karang atau balok semen kemudian disebar pada dasar perairan (Kamla, 2011).

Metode ini banyak digunakan oleh pembudidaya rumput laut di pantai Nambung NTB. Metode patok dasar ini bisa dilakukan di dibeberapa titik dari garis pantai yang masih terdapat sinar matahari. Namun belum diketetahui titik tanam yang tepat sehingga dapat mendukung pertumbuhan rumput laut hasil kultur jaringan. Selain dari titik tanam, kendala yangsering dihadapi oleh pembudidaya yang menggunakan metode patok dasar adalah berat bibit yang belum sesuaisehingga mampu bertahan dan tidak terbawa arus ataupun rontok. Oleh karena itu pentingnya dilakukannya penelitian ini guna untuk mengetahui titik tanam dan berat bibit yang tepat sehingga mampu menghasilkan pertumbuhan rumput laut Kappaphycus alvarezii hasil kultur jaringan yang optimal.

\section{Bahan dan Metode}

Penelitian ini dilaksanakan pada bulan Februari sampai April 2016 di pantai Nambung Kecamatan Sekotong Kabupaten Lombok Barat Provinsi Nusa Tenggara Barat. Alat yang digunakan adalah timbangan digital, meteran, refraktometer, disolved oxigen meter, thermometer, botol, gunting, kamera, palu, buku, pensil dan perahu. Bahan yang digunakan adalah bibit Kappaphycus alvarzii hasil kultur jaringan, patok kayu, tali poliethilen, tali rafia, dan air laut.

Rancangan percobaan yang digunakan pada penelitian ini yaitu Rancangan Acak Lengkap Faktorial (RAL Faktorial), terdiri atas 2 faktor, dimana faktor pertama merupakan 3 titik tanam yang berbeda (10 meter dari garis pantai, 20 meter dari garis pantai dan 30 meter dari garis pantai) dan faktor yang ke dua adalah berat bibit yang berbeda (Berat bibit 1,5 gram dan 50 gram).

Perlakuan tersebut adalah sebagai berikut :

PD1 : \pm 10 meter dari garis pantai (Kuljar 1,5 gr + Kuljar 50 gr)

PD2 : \pm 20 meter dari garis pantai (Kuljar 1,5 gr + Kuljar 50 gr)

PD3 : \pm 30 meter dari garis pantai (Kuljar 1,5 gr+ Kuljar 50 gr)

Pada perlakuan titik tanam dan berat bibit yang digunakan yakni :

Kuljar $\mathrm{A}=1,5$ gram

Kuljar $B=50$ gram

Setiap perlakuan diulang masing-masing 4 kali, sehingga didapatkan jumlah unit percobaan sebanyak 24 unit percobaan.

Parameter yang diukur adalah sebagai berikut:

1. Pertumbuhan Mutlak

Pertumbuhan mutlak rumput laut diamati dari awal hingga akhir penelitian, pertumbuhan mutlak dihitung menggunakan rumus pertumbuhan mutlak (Effendy, 2003).

Dengan:

$$
G=W t-W 0
$$

$$
\begin{aligned}
& \text { G : Pertumbuhan mutlak rata-rata (gr); } \\
& \text { Wt : Berat bibit pada akhir penelitian (gr); } \\
& \text { W0 : Berat bibit padaawal penelitian (gr). }
\end{aligned}
$$

\section{Laju Pertumbuhan Spesifik}

Laju pertumbuhan Spesifik (LPS) diperoleh dengan menimbang bibit basah rumput laut setiap 1 kali seminggu selama 35 hari. Untuk menghitung Laju Pertumbuhan Spesifik digunakan turunan dari persamaan Huisman (Dawes, 1994). 


$$
L P S=\frac{\ln W_{t}-\ln W_{o}}{t} x 100 \%
$$

Dengan:

LPS : Laju pertumbuhan spesifik rata-rata (\%);

Wt : Berat bibit pada tI (gr) (I = minggu I, minggu II...t)

W0 : Berat bibit awal (gr)

t : Periode pengamatan (minggu)

3. Kualitas Air

Parameter kualitas air yang diukur adalah suhu, salinitas, $\mathrm{pH}$, oksigen terlarut, Nitrit $\left(\mathrm{NO}_{2}\right)$ dan Phosfat (P).

Data dianalisis menggunakan Analysis of Variance (ANOVA) dan uji lanjut BNT (Beda Nyata Terkecil) atau LSD (Least Significant Difference) dengan taraf kesalahan 0,05.

\section{Hasil dan Pembahasan}

Hasil

Berikut adalah gambar hasil rumput kultur jaringan yang dibudidayakan di penelitian ini.

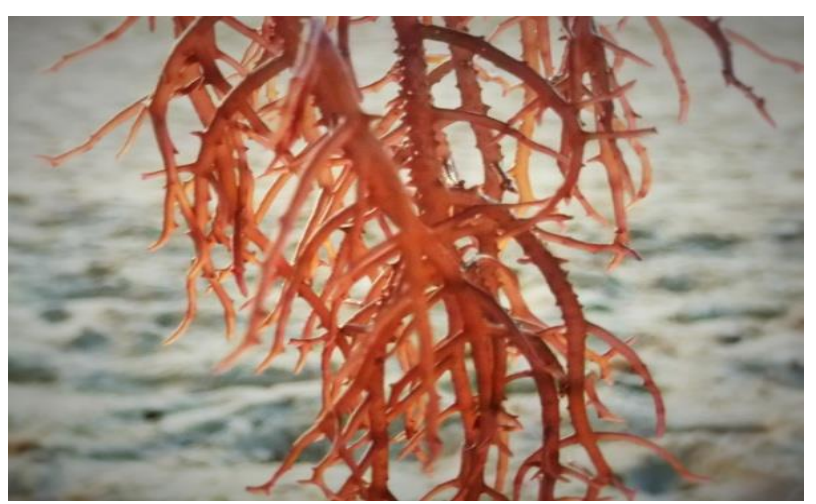

Gambar 1. Kappaphycus alvarezii Hasil Kultur jaringan Sumber : Dokumentasi Pribadi (2016)
Hasil analisis sidik ragam (ANOVA) pertumbuhan mutlak dan spesifik rumput laut Kappaphycus alvarezii dengan posisi tanam yang berbeda dapat dilihat pada tabel berikut ini

Tabel 1. Hasil Analisis Sidik Ragam Rata-Rata Pertumbuhan Mutlak terhadap Posisi Tanam

\begin{tabular}{ll}
\hline Posisi Tanam & Pertumbuhan Mutlak (gram) \\
\hline PD1 & $22,72^{\mathrm{c}}$ \\
PD2 & $33,32^{\mathrm{a}}$ \\
PD3 & $26,46^{\mathrm{b}}$ \\
\hline
\end{tabular}

Keterangan:

Angka-angka yang ditandai dengan huruf (superscript) yang berbeda pada tiap kolom yang sama menunjukkan ada perbedaan $(p<0.05)$ antar perlakuan.

PD1 : posisi tanam 10 meter dari garis pantai,

PD2 : posisi tanam 20 meter dari garis pantai, PD3 : posisi tanam 30 meter dari garis pantai.

Tabel 2.Hasil Analisis Sidik Ragam Rata-Rata Pertumbuhan Spesifik terhadap Posisi Tanam yang Berbeda

\begin{tabular}{ll}
\hline Posisi Tanam & Pertumbuhan Spesifik (\%) \\
\hline PD1 & $1,81^{\mathrm{c}}$ \\
PD2 & $2,75^{\mathrm{a}}$ \\
PD3 & $2,16^{\mathrm{b}}$ \\
\hline
\end{tabular}

Keterangan:

Angka-angka yang ditandai dengan huruf (superscript) yang berbeda pada tiap kolom yang sama menunjukkan ada perbedaan $(p<0.05)$ antar perlakuan.

PD1 : posisi tanam 10 meter dari garis pantai,

PD2 : posisi tanam 20 meter dari garis pantai,

PD3 : posisi tanam 30 meter dari garis pantai.

Nilai pertumbuhan mutlak dan spesifik rumput laut Kappaphycus alvarezii dapat dilihat pada Gambar berikut.

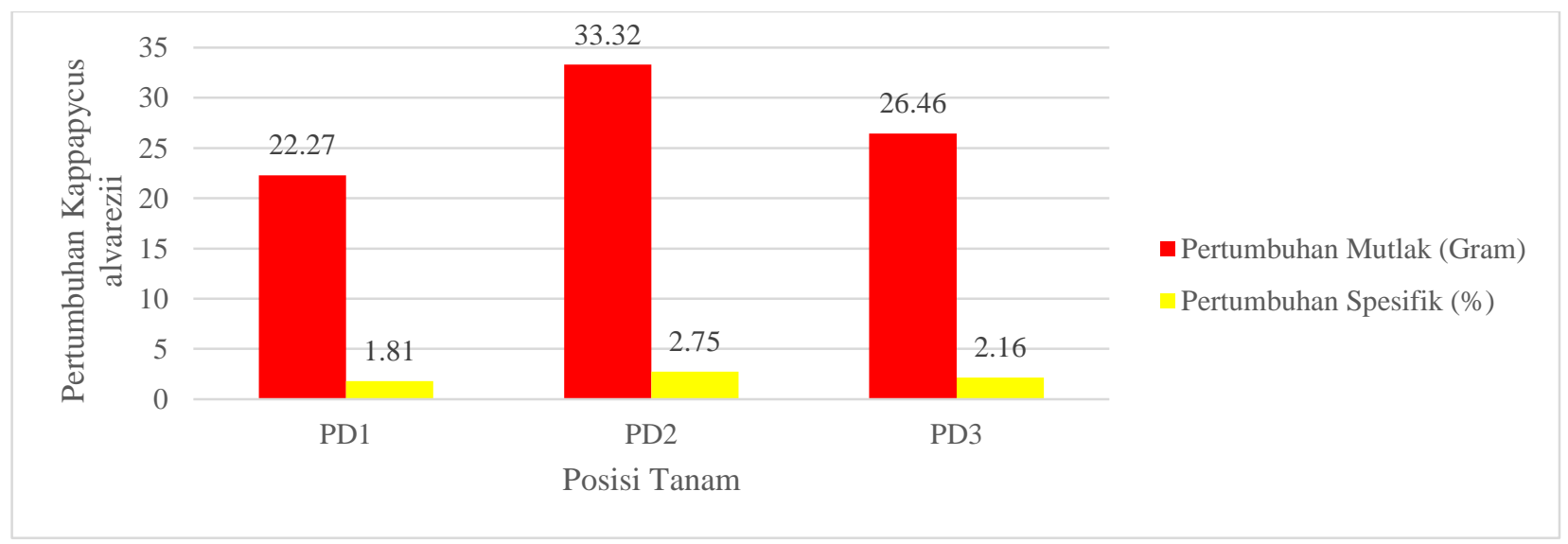

Gambar 2. Grafik Pertumbuhan Berdasarkan Posisi Tanam yang Berbeda 
Hasil analisis sidik ragam rata-rata pertumbuhan mutlak dan pertumbuhan spesifik terhadap berat bibit yang berbeda dapat di lihat pada tabel berikut ini.

Tabel 3. Hasil Analisis Sidik Ragam Pertumbuhan Mutlak terhadap Berat Bibit yang Berbeda

\begin{tabular}{ll}
\hline Berat Bibit & Pertumbuhan Mutlak (gram) \\
\hline A & $10,42^{\mathrm{b}}$ \\
B & $49,06^{\mathrm{a}}$ \\
\hline
\end{tabular}

Keterangan:

Angka-angka yang ditandai dengan huruf (superscript) yang berbeda pada tiap kolom yang sama menunjukkan ada perbedaan $(p<0.05)$ antar perlakuan.

A : berat bibit $\pm 1,5$ gram,

B : berat bibit \pm 50 gram.
Tabel 4. Hasil Analisis Sidik Ragam Pertumbuhan Spesifik terhadap Berat Bibit yang Berbeda

\begin{tabular}{ll}
\hline Berat Bibit & Pertumbuhan Spesifik (\%) \\
\hline A & $0,85^{\mathrm{b}}$ \\
B & $4,00^{\mathrm{a}}$ \\
\hline
\end{tabular}

Keterangan:

Angka-angka yang ditandai dengan huruf (superscript) yang berbeda pada tiap kolom yang sama menunjukkan ada perbedaan $(p<0.05)$ antar perlakuan.

$\mathrm{A}$ : berat bibit $\pm 1,5$ gram,

$\mathrm{B}$ : berat bibit \pm 50 gram.

Pertumbuhan mutlak dan spesifik tertinggi diperoleh berat bibit B $( \pm 50$ gram bibit kuljar $)$ dan berbeda nyata A $( \pm 1,5$ gram bibit kuljar)dan Pertumbuhan mutlak dan spesifik terhadap berat bibit yang berbeda dapat dilihat pada grafik berikut.

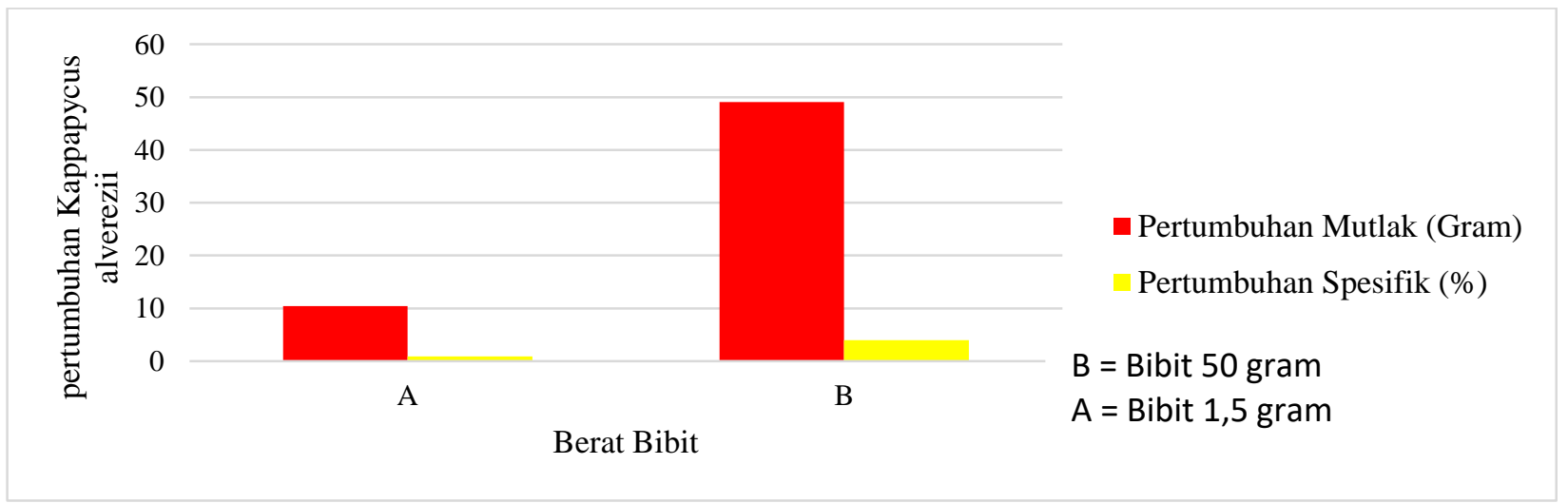

Gambar 3. Grafik Pertumbuhan Berdasarkan Berat Bibit yang Berbeda

Pertumbuhan rumput laut Kappaphycus alvareziidengan posisi tanam dan berat bibit yang berbeda pada akhir penelitian dapat dilihat pada tabel berikut.

Tabel 5.Pertumbuhan Akhir Rumput Laut Dengan Posisi Tanam Dan Berat Bibit yang Berbeda.

\begin{tabular}{lll}
\hline Perlakuan & $\begin{array}{l}\text { Pertumbuhan } \\
\text { Mutlak (gram) }\end{array}$ & $\begin{array}{l}\text { Pertumbuhan } \\
\text { Spesifik (\%) }\end{array}$ \\
\hline PD1A & 10,28 & 0,83 \\
PD1B & 36,21 & 2,95 \\
PD2A & 12,33 & 1,00 \\
PD2B & 60,55 & 4,94 \\
PD3A & 9,04 & 0,73 \\
PD3B & 48,14 & 3,92 \\
\hline
\end{tabular}

Selama pemeliharaan Kappaphycus alvarezii terus mengalami pertumbuhan setiap minggunya, sehingga didapatkan data pertumbuhan rata-rata rumput laut. Pertumbuhan rata-rata Kappaphycus alvarezii dapat dilihat pada Gambar 9 berikut.

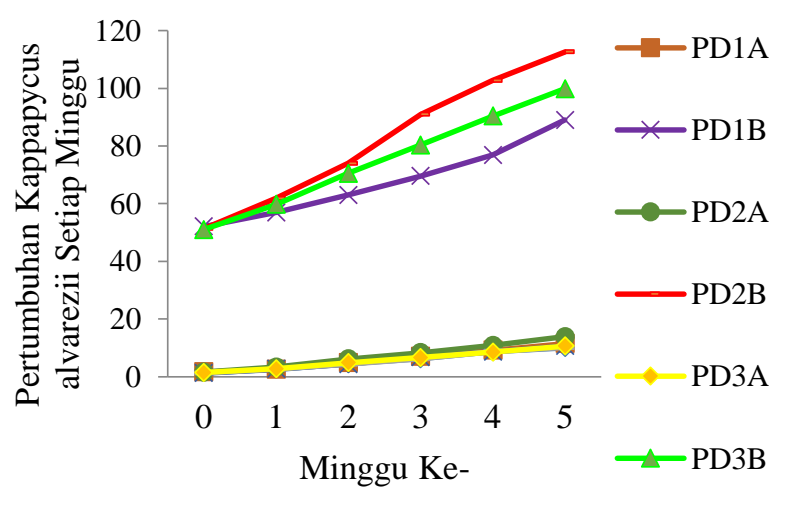

Gambar 4. Grafik Pertumbuhan Kappaphycus alvarezii Setiap Minggu (Interaksi). 
Berikut adalah hasil pengukuran kualitas air selama pemeliharaan rumput laut.

Tabel 6. Hasil Pengukuran Kualitas Air

\begin{tabular}{|c|c|c|c|}
\hline Parameter & Satuan & Rataan & Kisaran \\
\hline Salinitas & Ppm & $30-34$ & 28-35 (Kamla, 2011) \\
\hline Suhu & ${ }^{\circ} \mathrm{C}$ & $27-29$ & 20-30 (Kamla, 2011) \\
\hline DO & $\mathrm{Mg} / \mathrm{L}$ & $5,6-6,4$ & 5.1-6.6 (Aslan,1998) \\
\hline $\mathrm{pH}$ & - & $6,8-8,0$ & $\begin{array}{l}\text { 6,5-9 (Nurdjana, } \\
2010 \text { ) }\end{array}$ \\
\hline $\mathrm{NO}_{2}-\mathrm{N}$ & $\mathrm{Mg} / \mathrm{L}$ & 0,02 & $\begin{array}{l}0.01-0.7 \\
\text { (Wardoyo,1978dalam } \\
\text { Kamla, 2011) }\end{array}$ \\
\hline $\mathrm{PO}_{4}-\mathrm{P}$ & $\mathrm{Mg} / \mathrm{L}$ & $\begin{array}{l}0,034- \\
0,70\end{array}$ & $\begin{array}{l}0,051-1,00 \\
\text { (Nurdjana, 2010) }\end{array}$ \\
\hline
\end{tabular}

Nilai parameter kualitas air yang terukur masih dalam kisaran optimal sehingga dianggap mampu meningkatkan pertumbuhan Kappaphycus alvarezii.

\section{Pembahasan}

Hasil penelitian menunjukkan bahwa posisi tanam rumput laut dan berat bibit yang digunakan memberikan pengaruh terhadap pertumbuhan mutlak. Interaksi antara posisi tanam dan berat bibit juga memberikan pertumbuhan Kappaphycus alvarezii yang berbeda nyata. Saputra (2013) menyatakan bahwa penentuan posisi tanam rumput laut mempengaruhi pertumbuhan rumput laut, sehingga penting bagi pembudidaya untuk menentukan posisi budidaya rumput laut hingga mendukung pertumbuhan rumput laut.

Berdasarkan hasil penelitian rata-rata pertumbuhan mutlak Kappaphycus alvarezii pada masing-masing posisi tanam yang berbeda menunjukkan adanya perbedaan, dimana hasil analisis sidik ragam (ANOVA) memberikan pengaruh nyata terhadap pertumbuhan rumput laut Kappaphycus alvarezii antara setiap posisi tanam baik itu PD1 (10 meter dari garis pantai), PD2 (20 meter dari garis pantai), maupun PD3 (30 meter dari garis pantai). Perbedaan rata-rata pertumbuhan mutlak rumput laut Kappaphycus alvarezii pada masing-masing posisi tanam dikarenakan karakteristik ekologis perairan yang berbeda menjadi faktor perbedaan rata-rata pertumbuhan mutlak pada setiap posisi. Menurut Atmadja (2007) bahwa rumput laut termasuk tumbuhan yang dalam proses metabolismenya memerlukan kesesuaian faktor-faktor fisika dan kimia perairan seperti gerakan air, suhu, kadar garam, nutrisi atau zat hara (seperti nitrat dan fosfat), dan pencahayaan sinar.

Rendahnya pertumbuhan rumput laut pada PD1 karena adanya beberapa kondisi yang mempengaruhi baik fisika, kimia maupun kondisi ekologis lainnya yang mempengaruhi pertumbuhan rumput laut. Perairan yang mengandung partikel lumpur dapat menghambat pertumbuhan Kappaphycus alvarezii. Hal ini mengacu pada keberadaan partikel lumpur yang merata melekat padathallus rumput laut yang di setiap rumpun terdeteksi pada saat pengontroan yang dilakukan setiap minggunya. Parenrengi et al., (2010) menyatakan bahwa arus yang membawa partikel zat padat yang akan menempel pada talus rumput laut akan mengganggu proses fotosintesis. Sumber partikel lumpur tersebut diduga berasal dari limbah rumah tangga yang tinggal didekat area budidaya serta buangan limbah penambangan emas yang tidak ramah lingkungan dan jumlah atau volumenya akan meningkat jika hujan turun. Selain itu faktor lain yang dianggap berpengaruh ialah ketersedian unsur hara dalam hal ini fosfor dikarenakan oleh kandungan fosfor yang lebih rendah dibanding posisi tanam lain, kisaran salinitas, serta kecepatan arus kurang berperan aktif dalam mendukung pertumbuhan rumput laut di PD1.

Pada posisi tanam 2 (PD2) pertumbuhannya lebih tinggi dibandingkan dengan PD1 dan PD3. Faktor yang dianggap berpengaruh bagi pertumbuhan rumput laut di PD2 adalah secara geografis lebih jauh dari aktifitas masyarakat yang tinggal di pesisir, kecepatan arus pada posisi ini cukup membantu bagi pertumbuhan maupun perkembangan rumput laut. Dimana letak geografis PD2 ini yang jauh dari aktifitas daratan. Hal ini didukung oleh pernyataan Prihaningrum et al., (2001) menyatakan bahwa untuk mendukung keberhasilan budidaya rumput laut usahakan menghindari lokasi yang berdekatan dengan sumber pencemaran air, seperti industri serta bersandarnya kapal-kapal. Karena kondisi tersebut dikhawatirkan dapat menurunkan kualitas air, yang pada akhirnya akan menurunkan daya dukung lingkungan terhadap perkembangan rumput laut yang dikembangkan.

Pada PD3 memperoleh nilai yang lebih rendah dan berbeda nyata dengan PD2 tetapi lebih 
tinggi dibandingkan dengan PD1, hal ini karena unsur hara pada posisi ini yang kurang mendukung pertumbuhan Kappaphycus alvarezii secara maksimal, dimana pada PD3 kandungan fosfat yang lebih rendah dari PD2 yaitu sebesar $0,53 \mathrm{mg} / \mathrm{l}$ dan PD2 sebesar 0,70 $\mathrm{mg} / \mathrm{l}$ sedangkan pada PD1 kandungan fosfat hanya sebesar 0,034 gram, mengingat fosfat merupakan unsur hara makro yang sangat dibutuhkan rumput laut untuk mendukung pertumbuhannya. Kekurangan unsur $\mathrm{P}$ dapat diamati dari adanya gejala tertundanya pematangan sel. Menurut Buckman dan Brady (1982) dalamPurwanto (2008), fosfor berpengaruh baik pada proses pembelahan sel dan pembentukan lemak pada organisme.

Selain posisi tanam, berat bibit juga mampu meningkatkan pertumbuhan mutlak rumput laut Kappaphycus alvarezii. Berdasarkan hasil analisis sidik ragam (ANOVA) berat bibit yang berbeda memberikan pengaruh terhadap pertumbuhan. Berat bibit $\mathrm{B}$ dengan berat \pm 50 gram hasil kultur jaringan memberikan pertumbuhan tertinggi yakni sebesar 49,09 gram. Hal ini karena berat bibit yang tepat dan dianggap mampu bertahan dari hempasan ombak, ukuran thallus yang besar dan lebat serta keunggulan dari bibit hasil kultur jaringan. Hartono et al, (2015) menyatakan bahwa bibit yang digunakan baiknya bibit dengan berat 50-150 gram, mempunyai thallus muda dan kuat, mudah diikat dan tahan dari hempasan ombak. Sehingga bibit mampu bertahan, tumbuh dan berkembang dengan cepat. Menurut Dedy (2013), bibit hasil kultur jaringan merupakan alternatif yang dapat digunakan para petani rumput laut untuk mengoptimalkan hasil panen karena bibit hasil kultur jaringan memiliki pertumbuhan yang relatif lebih cepat, memiliki thallus yang kuat dan bercabang banyak serta terbebas dari serangan hama dan penyakit. Sarifin (2012) menyatakan bahwa kultur jaringan merupakan suatu metode untuk mengisolasi bagian dari tanaman (pada rumput laut adalah tallus) dan menumbuhkannya dalam kondisi yang aseptik dan steril dalam wadah tertutup, sehingga bagian tersebut dapat memperbanyak diri dan bergenerasi menjadi tanaman lengkap dan memiliki sifat unggul yang sama seperti tanaman induknya dan terbebas dari serangan hama dan penyakit. Bibit hasil kultur jaringan memiliki kecepatan pertumbuhan yang tinggi dan bebas dari seranga penyakit, sehingga produktivitasnya akan lebih tinggi.
Pertumbuhan mutlak pada bibit A dengan berat $\pm 1,5$ gram tetap mengalami pertumbuhan, namun memperoleh nilai pertumbuhan yang rendah, hal ini dikarenakan bibit yang bterlalu kecil sehingga dapat menyebabkan kerontokan ataupun terbawa ombak. Ismariani (2015) menyatakan bahwa penggunaan berat bibit yang berbeda sangat berpengaruh terhadap pertumbuhan rumput laut, hal ini diduga karena semakin besar jumlah bibit rumput laut pada saat ditanam maka akan semakin tinggi pertumbuhannya.

Pertumbuhan spesifik tertinggi berdasarkan posisi tanam diperoleh PD2 dengan nilai LPS sebesar 2,75\% dan berturut-turut diikuti PD3 dengan nilai LPS sebesar 2,16\% serta PD1 sebesar $1,81 \%$. Perbedaan ini karena karakteristik ekologis perairan yang berbeda menjadi salah satu faktor perbedaan rata-rata pertumbuhan spesifik pada setiap posisi, sehingga nutrisi serta kualitas air yang berbeda tersebut menyebabkan perbedaan yang diterima oleh rumput laut. Sedangkan LPS berdasarkan berat bibit nilai pertumbuhan spesifik tertinggi diperoleh berat bibit B sebesar $4.00 \%$ serta nilai LPS berat bibit A sebesar $0,85 \%$. Perbedaan pertumbuhan spesifik ini tidak lepas dari perbedaan berat bibit awal. Oleh karena itu, penggunaan berat bibit sangat berpengaruh terhadap pertumbuhan harian rumput laut, dimana penggunaan berat bibit 50 gram memiliki nilai LPS yang lebih tinggi dan nilai tersebut sudah masuk dalam standar nilai LPS yang dapat menguntungkan bagi pembudidaya. Gunawan (1987) menyatakan bahwa laju pertumbuhan bobot rumput laut yang dianggap cukup menguntungkan adalah di atas $3 \%$ pertambahan berat perhari, dan didukung oleh Supit (1989) dalam Mamang (2008), mengemukakan bahwa laju pertumbuhan Eucheuma cattonii yang ditanam di Goba Labangan Pasir Pulau Pari bahwa laju pertumbuhan rumput laut yang baik adalah diatas $3 \%$. Ukuran bibit rumput laut yang ditanam berpengaruh terhadap laju pertumbuhan dan bibit thallus yang berada bagian ujung akan memberikan laju pertumbuhan lebih tinggi dibandingkan dengan bibit thallus dari bagian pangkal.

Pertumbuhan akhir, mutlak dan spesifik tertinggi kombinasi posisi tanam dan berat bibit tertinggi diperoleh kombinasi PD2B. Pertumbuhan akhir sebesar 112,66 gram, pertumbuhan mutlak sebesar 60,55 gram dan spesifik sebesar 4,94\% dimana persentase tersebut sudah melebihi 
persentase standar pertumbuhan spesifik yang menguntungkan pembudidaya rumput laut sebesar 3\%, hal ini didukung oleh Gunawan (1987) bahwa laju pertumbuhan bobot rumput laut yang dianggap cukup menguntungkan adalah di atas $3 \%$ pertambahan berat perhari. Tingginya ke tiga pertumbuhan tersebut diduga karena tingginya nilai fosfat di PD2 serta berat bibit yang sesuai sehingga mampu mendukung pertumbuhan secara maksimal.

Nilai parameter kualitas air masih dalam kisaran optimal untuk pertumbuhan Kappaphycus alvarezii, dimana Kappaphycus alvarezii mempunyai kisaran-kisaran kualitas air optimal dalam mendukung pertumbuhannya. Purwanto (2008) menyatakan bahwa faktor yang sangat berpengaruh pada pertumbuhan jenis Kappaphycus alvareziiyaitu cukup arus dengan salinitas (kadar garam) yang stabil yaitu berkisar 28-34 ppm, suhu berkisar antara $20-28^{\circ} \mathrm{C}$ dengan fluktuasi harian maksimum $4^{\circ} \mathrm{C}$. Oleh karenanya, rumput laut jenis ini akan hidup baik bila jauh dari muara sungai. Dan didukung oleh Kawaroe et al., (2012) rumput laut hidup dan tumbuh pada perairan dengan kisaran suhu air antara $20-28^{\circ} \mathrm{C}$, namun masih ditemukan tumbuh pada suhu $31^{\circ} \mathrm{C}$. Sulistijo dan Atmadja (1996) dalam Mamang (2008) menyatakan Baku mutu DO untuk rumput laut adalah lebih dari $5 \mathrm{mg} / \mathrm{l}$, hal ini berarti jika oksigen terlarut dalam perairan mencapai $5 \mathrm{mg} / \mathrm{l}$ maka metabolisme rumput laut dapat berjalan dengan optimal. Supit (1989) dalam Mamang (2008) menyatakan bahwa hampir seluruh alga menyukai kisaran $\mathrm{pH}$ 6,8-9,6. Wardoyo (1978) dalam Kamla (2011) bahwa kandungan fosfat sangat baik bila berada pada kisaran 0,10-0,20 mg/1 sedangkan nitrat dalam kondisi berkecukupan biasanya berada pada kisaran antara 0,01- 0,7 mg/1. Dengan demikian dapat dikatakan perairan tersebut mempunyai tingkat kesuburan yang baik dan dapat digunakan untuk kegiatan budidaya laut.

\section{Kesimpulan}

Kesimpulan penelitian ini adalah penggunaan titik tanam dan berat bibit memberikan interaksi satu sama lain, dimana penggunaan posisi tanam 2 dan berat bibit $\mathrm{B}( \pm 50$ gram $)$ (PD2B) menghasilkan pertumbuhan tertinggi akhir tertinggi yaitu 112,66 gram, pertumbuhan mutlak sebesar 60,55 gram serta pertumbuhan spesifik $4,94 \%$.

\section{Daftar Pustaka}

Atmadja, W., S. (2007). Apa Rumput Laut itu Sebenarnya? Divisi Penelitian dan Pengembangan Seaweed. Kelompok Studi Rumput Laut Kelautan. UNDIP. Semarang. 8 hal.

Dedy, Pongarrang. (2013). Pengaruh Jarak Tanam Dan Bobot Bibit Terhadap Pertumbuhan Rumput Laut (Kappaphycus Alvarezii) Menggunakan Metode Vertikultur. Skripsi. (Tidak Untuk Dipublikasi). Universitas Halu Oleo Kampus Hijau Bumi Tridharma Anduonohu Kendari. Kendari.

Hartono. Mudeng. J.D. \& Mondoringin. L.J., (2015). Pertumbuhan Rumput Laut Kappaphycus alvareziiyang Dikultur Menggunakan Dua Jenis Tali Ris dengan Kondisi Berbeda. Program Studi Budidaya Perairan FPIK Unsrat Manado. Manado. Jurnal Budidaya Perairan, 3(1) : 35-42.

Ismariani, B.S. (2015). Pertumbuhan Bibit Rumput Laut (Kappaphycus alvarezii) hasil Kultur Jaringan di Balai Perikanan Budidaya Laut $(B P B L)$ Lombok dengan Berat Bibit yang Berbeda. Skripsi. Budidaya Perairan Universitsa Mataram. Mataram

Kamla, Y. (2011). Produksi, Pertumbuhan dan Kandungan Karaginan Rumput Laut Kappaphycus alvarezii. Disertasi Program Pasca Sarjana Universitas Hasanudin. Makassar. 59 hal.

Kementrian Kelautan Dan Perikanan (KKP). (2014). Strategi Pengembangan Infrastruktur Perikanan Dalam Mendukung Peningkatan Daya Saing. Info Kajian Bapenas, 8 (2) : 1018.

Kementerian Kelautan dan Perikanan (KKP). (2015). Buku Statistik : Provinsi dalam Angka 2014. Jakarta (ID) : Pusat Data Statistik dan Informasi. Kementerian Kelautan dan Perikanan.

Mamang, R. (2008). Laju Pertumbuhan Bibit Rumput Laut Eucheuma Cattonii Dengan Perlakuan Asal Thallus Terhadap Bobot Bibit Di Perairan Lakeba, Kota Bau-Bau, Sulawesi Tenggara. Institut Pertanian Bogor. Bogor.

Parenrengi, A., Syah, R., dan Suryati, E., (2010). Budi Daya Rumput Laut Penghasil 
Karaginan (Karaginofit). Badan Penelitian dan Pengembangan Kelautan dan Perikanan Kementerian Kelautan dan Perikanan Republik Indonesia. 52 hal. Paula E.J and Pereira R.T.

Prihanigrum A., M. Meiyana dan Evalawati. (2001). Biologi Rumput laut; Teknologi Budidaya Rumput Laut (Kappaphycus alvarezii). Petunjuk Teknis. Departemen Kelautan dan Perikanan. Direktorat Jenderal Perikanan Budidaya. Balai Budidaya Laut. Lampung. 66 hal.

Purwanto, et al. (2008). Rumput Laut. Penebar Swadaya. Jakarta.

Saputra, R., Rahmat. S.P. \& Abdul. M.B. (2013). Growth and Caraginan Content Analysis of Seaweed Kappaphycus alvarezii at Different Mining Area in Lasolo Subdistrict North Konawe. Program Studi Budidaya Perairan FPIK Universitas Kendari. Jurnal Mina Laut Indonesia. 03 (12) : 55-67. 